\title{
Effects of post mortem temperature on rigor tension, shortening and pH in ostrich muscle
}

\author{
S.StC. Botha ${ }^{1,2}$, L.C. Hoffman ${ }^{1 \#}$ and T.J. Britz ${ }^{2}$ \\ ${ }^{1}$ Department of Animal Sciences, \\ ${ }^{2}$ Department of Food Science, University of Stellenbosch, P. Bag X1, Matieland 7602, South Africa
}

\begin{abstract}
Fully developed rigor mortis in muscle is characterised by maximum loss of extensibility. The course of post mortem changes in ostrich muscle was studied by following isometric tension, shortening and change in $\mathrm{pH}$ during the first $24 \mathrm{~h}$ post mortem within muscle strips from the muscularis gastrocnemius, pars interna at constant temperatures of $7{ }^{\circ} \mathrm{C}$ and $37^{\circ} \mathrm{C}$. Maximum shortening was significantly higher at $37{ }^{\circ} \mathrm{C}(33.4$ $\pm 3.57 \%)$ than at $7{ }^{\circ} \mathrm{C}(10.7 \pm 2.63 \%)$. The rate of rigor development was temperature dependent, reaching a maximum tension at $4.08 \pm 3.89 \mathrm{~h}$ post mortem in muscle strips at $37^{\circ} \mathrm{C}$; while at $7^{\circ} \mathrm{C}$ maximum tension was reached at $10.5 \pm 6.47 \mathrm{~h}$ post mortem. It was concluded that the completion of rigor occurred at the point of minimum $\mathrm{pH}$.
\end{abstract}

Keywords: Rigor mortis, rigor tension, muscle shortening, ostrich, rigor shortening, cold-shortening, hotdeboning, rate of $\mathrm{pH}$ decline

${ }^{\#}$ Corresponding author. E-mail: 1ch@sun.ac.za

\section{Introduction}

During the development of rigor mortis muscles become inextensible due to the sum of each muscle fibre going into full rigor, with irreversible cross-bridge formation (actomyosin) of the contractile components, actin and myosin (Hwang et al., 2003). Bendall (1973) defined the onset of rigor mortis as the beginning of the decrease in extensibility of the muscle, while completion of rigor is seen as the maximum loss of extensibility (Honikel et al., 1983). The rigor process involves first a delay period, when the level of ATP (adenosine triphosphate) is constant, CP (creatine phosphate) is decreasing rapidly, and there is a slow production of lactate and no onset of rigor development. This is followed by a rapid phase when CP is low enough to initiate a rapid decline in ATP concentration, which is accompanied by a decreasing extensibility of the muscle due to irreversible cross-bridge formation of actin and myosin (Bendall, 1973). Shortening of muscles occurs before the onset of rigor mortis since contraction requires a minimum ATP concentration and an increased level of $\mathrm{Ca}^{2+}$ ions around the myofibrils (Honikel et al., 1983).

Cold-shortening occurs when muscles are exposed to low temperatures (below $10{ }^{\circ} \mathrm{C}$ to $15{ }^{\circ} \mathrm{C}$ ) early post mortem, when ATP and pH levels are still high (pH above 6.2) (Nuss \& Wolfe, 1980-81; Lawrie, 1998). On the other hand, rigor tension occurs much later and at any temperature between $0{ }^{\circ} \mathrm{C}$ and $37^{\circ} \mathrm{C}$, reaching maximum values when ATP levels have been depleted and $\mathrm{pH}$ is at a minimum value (Nuss \& Wolfe, 198081). The stiffness characteristic of rigor mortis is then maintained by continuous tension exerted by the cross-bridges between myosin and actin filaments (Pearson \& Young, 1989).

In both pork and beef muscles shortening is a major determinant of tenderness when the tissue has not yet entered rigor mortis and when the rate of muscle $\mathrm{pH}$ decline is rapid (Møller \& Vestergaard, 1987; Smulders et al., 1990). Tornberg (1996) has reported that a more shortened beef muscle has a higher cooking loss and a higher number of fibres per unit cross-area, leading to higher Warner-Bratzler peak shear force values and greater toughness. Marsh \& Leet (1966) and Locker \& Daines (1975) also reported shortened beef muscles to be tougher, while Powell (1978) and Honikel et al. (1980) reported higher drip losses in contracted muscles than in non-shortened muscles.

Knowledge of the course of rigor mortis and post mortem $\mathrm{pH}$ changes, as well as the influence of temperature, on the onset of rigor mortis, might help to reduce purge and initial toughness in hot-deboned ostrich muscles. The aim of this study was therefore to investigate the development of isometric tension (developing tension while the muscle is prevented from contracting) and muscle shortening in ostrich m. gastrocnemius, pars interna during rigor mortis at $7{ }^{\circ} \mathrm{C}$ and at $37{ }^{\circ} \mathrm{C}$ in an attempt to determine the time 
course of rigor, $\mathrm{pH}$ decline, and the degree and extent of shortening (occurrence of cold-shortening and/or rigor shortening).

\section{Materials and Methods}

Ten rested (12 h of lairage) ostriches (Struthio camelus var. domesticus) from different farms were slaughtered at ages of between 10 and 14 months, as described by Wotton \& Sparrey (2002), during the summer months of 2004 (February to April) at an EU approved ostrich abattoir in Malmesbury, South Africa. The right leg m. gastrocnemius, pars interna was removed and mounted within $20 \mathrm{~min}$ to $1 \mathrm{~h}$ after stunning and exsanguination. Two muscle strips (dimensions: $10 \times 10 \times 30 \mathrm{~mm}$; mass: 1.5 to $3 \mathrm{~g}$ ) were carefully cut, parallel to the fibre axis, from the 10 individual muscles. The cross-sectional area of each muscle strip was calculated with the use of Rigotech ${ }^{\circledR}$ software (Rigotech version 3.0, CReoLogica, 1999, Sweden) by using the length and the weight of the strip, together with the density of the muscle $\left(1.06 \mathrm{~g} / \mathrm{cm}^{3}\right)$. Muscle strips were glued onto the aluminium discs of two separate rigometers (Rigotech ${ }^{\circledR}$, CReoLogica, 1999, Sweden) at constant temperatures of $7{ }^{\circ} \mathrm{C}$ and $37^{\circ} \mathrm{C}$, respectively, with the use of cyanoacrylate glue (Lynlim Superglue, Norway). To provide an anaerobic environment and to minimise dehydration, the strips were covered with a mixture of paraffin oil and petroleum jelly. Rigor tension and muscle shortening were recorded during rigor mortis every $15 \mathrm{~min}$ for the first 23 to $24 \mathrm{~h}$ post mortem. Rigor tension was expressed as force per unit area $\left(\mathrm{mN} / \mathrm{mm}^{2}\right)$ and shortening was expressed as the percentage decrease in length relative to the initial length of the muscle strip.

Muscle $\mathrm{pH}$ and temperature were measured by using SenTix 41 probes (Germany), connected to portable $\mathrm{pH}$ meters 340i (WTW, GmbH \& Co. KG, Weilheim, Germany). The probes were placed directly into larger portions of the same muscles used for the measurement of rigor tension and muscle shortening. These portions were also covered with paraffin oil and petroleum jelly and placed in the rigometers at 7 and $37^{\circ} \mathrm{C}$, respectively. Muscle $\mathrm{pH}$ and temperature were continuously measured every $10 \mathrm{~min}$ for the first 23 to $24 \mathrm{~h}$ post mortem.

The changes in $\mathrm{pH}$ and temperature $\left({ }^{\circ} \mathrm{C}\right)$ were also measured continuously, every $10 \mathrm{~min}$ for the first 23 to $24 \mathrm{~h}$, in the intact left leg m. gastrocnemius, pars interna from the same ostrich carcasses by inserting the probes to a depth of 4 to $5 \mathrm{~cm}$ into the intact muscles at $1 \mathrm{~h}$ post mortem. At approximately $2 \mathrm{~h}$ post mortem these carcasses were moved to the refrigerator $\left(<4{ }^{\circ} \mathrm{C}\right)$ at the abattoir for $24 \mathrm{~h}$.

The experimental design was a complete randomised block design, replicated in 10 blocks (ostrich carcasses), with two treatments for the rigometer results (muscle strips at 7 and $37{ }^{\circ} \mathrm{C}$, respectively) and with three treatments for the $\mathrm{pH}$ and temperature results (intact muscle, and muscle strips at 7 and $37{ }^{\circ} \mathrm{C}$, respectively). The data was subjected to factorial analysis of variance (ANOVA) using SAS version 8.2 Statistical Software (SAS, 1999). Shapiro-Wilk tests were performed for testing non-normality (Shapiro \& Wilk, 1965).

\section{Results and Discussion}

The analysis of variance (ANOVA) of the dependant variables: maximum tension $\left(\mathrm{mN} \cdot \mathrm{mm}^{-2}\right), \mathrm{pH}$ at maximum tension, time (h) post mortem to reach maximum tension, maximum shortening (\%), $\mathrm{pH}$ at maximum shortening, and the time (h) post mortem it took for the muscle strips to reach maximum shortening is presented in Table 1. Only the data for the time (h) to reach maximum shortening was not normally distributed $(\mathrm{P}<0.01)$ due to the occurrence of kurtosis. As the latter does not have a significant effect on the normality of the data (Glass et al., 1972), the data were analysed without transformation thereof. Temperature had no effect $(\mathrm{P}>0.05)$ on maximum tension $\mathrm{pH}$ or time to reach maximum tension (Table 2). Nuss \& Wolfe (1980-81) also indicated that the time to reach maximum tension in beef muscles decreased with an increase in temperature from $5{ }^{\circ} \mathrm{C}$ to $37^{\circ} \mathrm{C}$. Devine et al. (1999) demonstrated that the time required for bovine muscle to reach maximum tension was negatively correlated with temperature.

Similar to results found by Hertzman et al. (1993) for beef, maximum shortening for the ostrich muscle strips were significantly higher at $37{ }^{\circ} \mathrm{C}$ than at $7{ }^{\circ} \mathrm{C}$ (Table 2 ), while the $\mathrm{pH}$ values at the time of maximum shortening did not differ significantly $(\mathrm{P}>0.05)$ between $7{ }^{\circ} \mathrm{C}$ and $37^{\circ} \mathrm{C}$. This indicated that the muscle strips from the same individual ostrich carcass were, as expected, at the same initial energy levels (lactate and ATP concentrations) early post mortem, when the muscle strips were placed in the rigometers, leading therefore to similar $\mathrm{pH}$ values at the point of maximum tension development. The difference $(\mathrm{P}<0.01)$ in the time taken to reach maximum shortening for the main effect, namely 'temperature', 
indicated that the maximum shortening was reached sooner in the muscle strips at $37{ }^{\circ} \mathrm{C}(5.6 \pm 3.65 \mathrm{~h})$ than in the muscle strips at $7{ }^{\circ} \mathrm{C}(23.0 \pm 0.45 \mathrm{~h})$. This also indicated that the rate of muscle shortening was therefore faster at $37^{\circ} \mathrm{C}$ than at $7{ }^{\circ} \mathrm{C}$.

Table 1. Mean values ( \pm standard deviation) for maximum tension $\left(\mathrm{mN} \cdot \mathrm{mm}^{-2}\right), \mathrm{pH}$ at maximum tension, time (h) post mortem to reach maximum tension, maximum shortening $(\%), \mathrm{pH}$ at maximum shortening and the time (h) post mortem to reach maximum shortening at $7{ }^{\circ} \mathrm{C}$ and $37^{\circ} \mathrm{C}$, respectively

\begin{tabular}{lcc}
\hline \multirow{2}{*}{ Parameter } & \multicolumn{2}{c}{ Temperature } \\
\cline { 2 - 3 } & $7^{\circ} \mathrm{C}$ & $37^{\circ} \mathrm{C}$ \\
\hline Maximum tension $\left(\mathrm{mN} / \mathrm{mm}^{2}\right)$ & $347.5^{\mathrm{a}} \pm 41.53$ & $284.8^{\mathrm{a}} \pm 82.44$ \\
$\mathrm{pH}$ at maximum tension & $6.1^{\mathrm{a}} \pm 0.30$ & $5.9^{\mathrm{a}} \pm 0.13$ \\
Time (h) post mortem to reach maximum tension & $10.5^{\mathrm{a}} \pm 6.47$ & $4.1^{\mathrm{a}} \pm 3.89$ \\
Maximum shortening (\%) & $10.7^{\mathrm{a}} \pm 2.63$ & $33.4^{\mathrm{b}} \pm 3.57$ \\
$\mathrm{pH}$ at maximum shortening & $6.1^{\mathrm{a}} \pm 0.25$ & $6.1^{\mathrm{a}} \pm 0.37$ \\
Time (h) post mortem to reach maximum shortening & $23.0^{\mathrm{a}} \pm 0.45 \mathrm{~h}$ & $5.6^{\mathrm{b}} \pm 3.65$ \\
& & \\
${ }^{\mathrm{a} b}$ Different superscripts within rows differ at $\mathrm{P}<0.05$. & &
\end{tabular}

It has been hypothesised that the occurrence of higher maximum tension and less shortening at $7{ }^{\circ} \mathrm{C}$, compared to at $37{ }^{\circ} \mathrm{C}$, could be due to the release of calcium ions $\left(\mathrm{Ca}^{2+}\right)$ from the sarcotubular system at low temperatures (Cornforth et al., 1980; Whiting, 1980). Cornforth et al. (1980) and Whiting (1980) reported that the amount of $\mathrm{Ca}^{2+}$ released from bovine sarcoplasmic reticulum was least at $\mathrm{pH} 6.6$, when the temperature declined from $38{ }^{\circ} \mathrm{C}$ to $0{ }^{\circ} \mathrm{C}$. However, as the $\mathrm{pH}$ declined, the sarcoplasmic reticulum released increasingly more $\mathrm{Ca}^{2+}$ (Kanda et al., 1977), with essentially no activity near pH 5.0 (Whiting 1980). Both cold temperatures and low $\mathrm{pH}$ values lead to a decrease in the ability to accumulate $\mathrm{Ca}^{2+}$ and to an increase in the release of $\mathrm{Ca}^{2+}$ from the sarcoplasmic reticulum. Whiting (1980) found that the maximum $\mathrm{Ca}^{2+}$ uptake for bovine mitochondria was at $\mathrm{pH}$ 7.2. This activity decreased rapidly at a $\mathrm{pH}$ of 6.5 and was very low at a $\mathrm{pH}$ value of 5.5. Whiting (1980) thus concluded that the mitochondria would be the first to lose their ability to sequester $\mathrm{Ca}^{2+}$ as the post mortem $\mathrm{pH}$ declines from 6.5 to 6.0 . Temperatures below $15{ }^{\circ} \mathrm{C}$ also stimulate the release of $\mathrm{Ca}^{2+}$ ions from the sarcotubular system, enhancing the contractile actomyosin ATP-ase (Lawrie, 1998). With the increase in $\mathrm{Ca}^{2+}$ concentrations actin and myosin interconnect and, under normal circumstances, when there is enough ATP, the contractile ATP-ase provides the energy for the actin filament to be pulled inwards towards the centre of the sarcomere, causing the sarcomere to shorten.

For this study it was hypothesised that muscle strips from the same ostrich had similar energy levels when placed into the two separate rigometers at $7{ }^{\circ} \mathrm{C}$ and $37{ }^{\circ} \mathrm{C}$, respectively. However, as illustrated by data in Figure 1, the influence of the low temperature of $7^{\circ} \mathrm{C}$ slowed the rate of muscle contraction and therefore maximum tension, and maximum shortening was reached sooner in muscle strips at $37^{\circ} \mathrm{C}$ than in muscle strips at $7{ }^{\circ} \mathrm{C}$. It may also be hypothesised that the low temperature of $7{ }^{\circ} \mathrm{C}$ stimulated the release of $\mathrm{Ca}^{2+}$ ions from the sarcotubular system (Whiting, 1980; Hertzman et al., 1993). Simultaneously, the rate of anaerobic glycolysis and therefore the production of ATP and lactic acid was slower, leading to lower levels of ATP than in the muscle strips at $37^{\circ} \mathrm{C}$. This resulted in tension due to the binding between actin and myosin, but very little shortening, since there was not enough energy to cause the sarcomeres to shorten. In the absence of ATP the continuous tension is exerted by the cross-bridges formed between actin and myosin filaments (Pearson \& Young, 1989). This result differs from that of Hertzman et al. (1993) who noted that shortening occurs before tension. However, their lowest temperature was $15{ }^{\circ} \mathrm{C}$ whereas the temperature in this investigation was $7^{\circ} \mathrm{C}$ and the possibility of cold shortening and decreased anaerobic glycolysis from the present investigation may explain these differences. 
Table 2 Analysis of variance (ANOVA) of the dependant variables: maximum tension ( $\left.\mathrm{mN} / \mathrm{mm}^{2}\right), \mathrm{pH}$ at maximum tension, time (h) post mortem to reach maximum tension, maximum shortening (\%), $\mathrm{pH}$ at maximum shortening and the time (h) post mortem to reach maximum shortening with ostrich carcass and temperature $\left({ }^{\circ} \mathrm{C}\right)$ as main effects, as well as the Shapiro-Wilk test for non-normality

\begin{tabular}{|c|c|c|c|c|c|c|c|c|c|c|c|c|c|c|}
\hline \multirow[t]{2}{*}{ Source } & \multirow[t]{2}{*}{$\mathrm{df}$} & \multicolumn{2}{|c|}{$\begin{array}{l}\text { Max tension } \\
\left(\mathrm{mN} / \mathrm{mm}^{2}\right)\end{array}$} & \multicolumn{2}{|c|}{$\mathrm{pH}$ at max tension } & \multicolumn{2}{|c|}{$\begin{array}{c}\text { Time to reach max } \\
\text { tension }\end{array}$} & \multicolumn{2}{|c|}{$\begin{array}{c}\text { Max shortening } \\
(5 \%)\end{array}$} & \multicolumn{2}{|c|}{$\begin{array}{l}\mathrm{pH} \text { at max } \\
\text { shortening }\end{array}$} & \multicolumn{3}{|c|}{ Time to reach max shortening } \\
\hline & & MS & $\mathrm{P}$ & MS & $\mathrm{P}$ & MS & $\mathrm{P}$ & MS & $\mathrm{P}$ & $\mathrm{MS}$ & $\mathrm{P}$ & $\mathrm{df}$ & MS & $\mathrm{P}$ \\
\hline $\begin{array}{l}\text { Ostrich } \\
\text { carcass }\end{array}$ & 5 & 4877.631 & 0.3783 & 0.061 & 0.3501 & 15.471 & 0.8490 & 9.384 & 0.5398 & 0.153 & 0.1059 & 5 & 18.458 & 0.2096 \\
\hline Temperature & 1 & 11775.068 & 0.1321 & 0.072 & 0.2475 & 123.521 & 0.1454 & 1546.780 & $<0.0001$ & 0.004 & 0.7539 & 1 & 757.422 & 0.0006 \\
\hline Error & 5 & 3642.686 & & 0.039 & & 41.571 & & 10.309 & & 0.039 & & 4 & 7.726 & \\
\hline $\begin{array}{l}\text { Shapiro- } \\
\text { Wilk }\end{array}$ & & & 0.9941 & & 0.9163 & & 0.9032 & & 0.8620 & & 0.6608 & & & 0.9110 \\
\hline
\end{tabular}

df - Degree of freedom

MS - Mean sum of squares

$\mathrm{P}$ - Probability value of F-ratio test

Max - maximum 
In this study the higher maximum shortening (\%) at the higher temperature of $37^{\circ} \mathrm{C}$ could, in turn, be explained by the ATP levels (Hertzman et al., 1993) in conjunction with the influence of the high temperature on the sarcotubular system (Whiting, 1980). Hertzman et al. (1993) found a strong correlation between maximum shortening and ATP levels at the onset of the rapid shortening phase. These researchers explained the higher shortening at $37{ }^{\circ} \mathrm{C}$ compared to $15^{\circ} \mathrm{C}$ to be due to the higher ATP level at the higher temperature. Whiting (1980) showed that the $\mathrm{Ca}^{2+}$ sequestering ability of the mitochondria (from beef muscles) at $\mathrm{pH} 7.2$ decreased rapidly at temperatures higher than $20^{\circ} \mathrm{C}$ and was practically non-existent after $30 \mathrm{~min}$ at $37^{\circ} \mathrm{C}$. On the other hand, the $\mathrm{Ca}^{2+}$ sequestering activity of the sarcoplasmic reticulum remained relatively constant at temperatures up to $37{ }^{\circ} \mathrm{C}$ at $\mathrm{pH} 7.2$, whereafter its ability to sequester $\mathrm{Ca}^{2+}$ decreased rapidly at temperatures higher than $37^{\circ} \mathrm{C}$. Therefore, for this study, it was hypothesised that the reduced stability of the $\mathrm{Ca}^{2+}$ uptake ability of especially mitochondria, together with a faster decline in $\mathrm{pH}$ at $37^{\circ} \mathrm{C}$ compared to $7^{\circ} \mathrm{C}$ (see Figure 2), could initiate rigor shortening at higher ATP levels, resulting in the higher maximum shortening at $37^{\circ} \mathrm{C}$.

Isometric tension results for beef muscles, obtained by Hertzman et al. (1993), were characterised by a delay phase preceding the development of tension, and this delay was shorter at $37^{\circ} \mathrm{C}$ than at $15^{\circ} \mathrm{C}$. In the case of shortening, these authors reported a delay period at $15{ }^{\circ} \mathrm{C}$, while at $37{ }^{\circ} \mathrm{C}$ shortening started immediately. From the data in Figure 1 it can be seen that, similar to the findings of Hertzman et al. (1993), there was a short delay period at both $7{ }^{\circ} \mathrm{C}$ and $37^{\circ} \mathrm{C}$, before the onset of tension development, with the delay period being shorter at $37^{\circ} \mathrm{C}$ than at $7{ }^{\circ} \mathrm{C}$. The development of shortening started almost immediately in muscle strips at $37{ }^{\circ} \mathrm{C}$; while at $7{ }^{\circ} \mathrm{C}$ there was a delay of approximately 100 min before the onset of shortening.

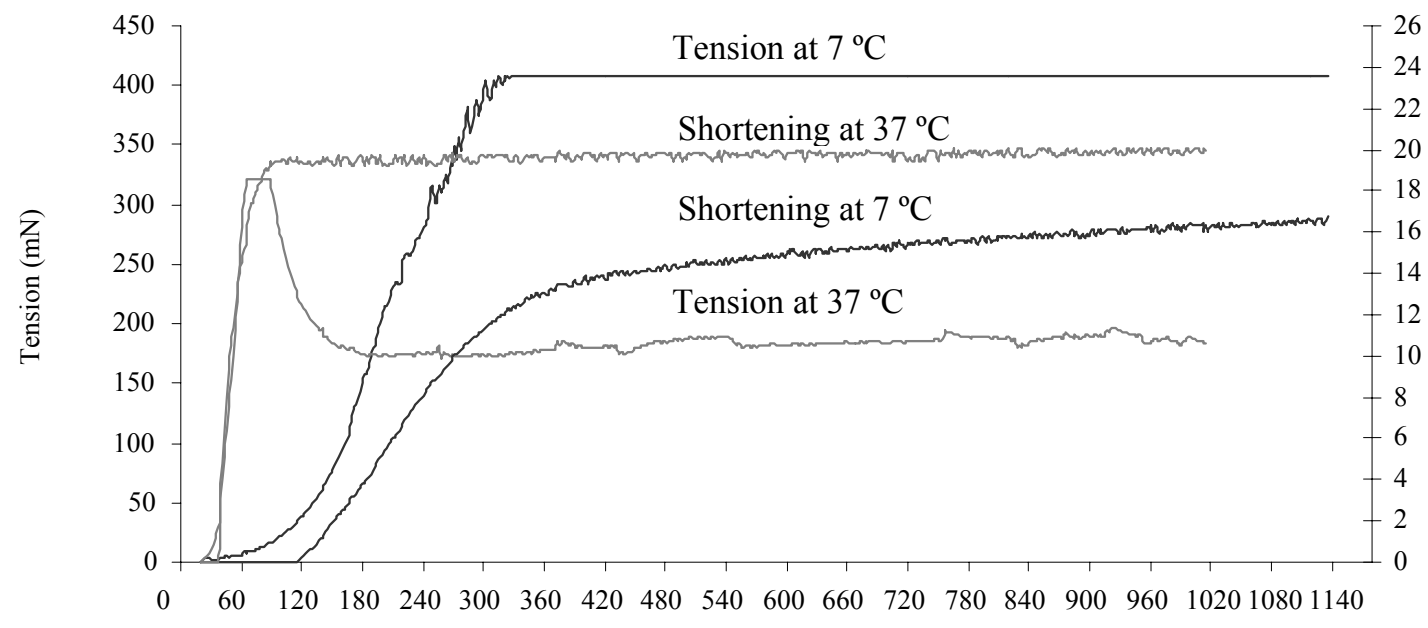

Time post-mortem (min)

Figure 1 Development of muscle rigor tension and shortening from the time (20 min post mortem) the muscle strips from an individual ostrich were placed in the rigometers, maintained at $7{ }^{\circ} \mathrm{C}$ and $37{ }^{\circ} \mathrm{C}$, respectively.

What is also noteworthy is that the tension peak for the muscle strips at $37{ }^{\circ} \mathrm{C}$ was followed by a decrease in tension, while at $7{ }^{\circ} \mathrm{C}$ the maximum tension remained constant. The constant tension at $7{ }^{\circ} \mathrm{C}$, as depicted in Figure 1, was initially attributed to a possible, unexplained technical failure of the rigometer. However, the tension data obtained from the muscle strips from the other ostriches at $7{ }^{\circ} \mathrm{C}$ did in fact follow the same pattern - a constant maximum tension (measured up to $22 \mathrm{~h}$ post mortem in the rigometer). The decrease in tension at $37^{\circ} \mathrm{C}$ could be ascribed to proteolysis or the initial ageing process of the muscle after fully developed rigor at high temperatures. The rate of tenderisation early post mortem would be enhanced in muscles that are at higher temperatures since the extent of proteolysis is temperature dependent; it is greater at $37{ }^{\circ} \mathrm{C}$ than at $5{ }^{\circ} \mathrm{C}$. This phenomenon was also shown in beef by Hertzman (1993), who ascribed 
the fall in tension to proteolysis. This was studied further by Tornberg et al. (2000) who studied the effect of pre-rigor conditions in beef under various temperature and $\mathrm{pH}$ regimens and also noted and postulated that this decrease is linked closely to proteolysis. What is noteworthy and warrants further research, is the very rapid occurrence of this phenomenon in ostrich muscle.

It was hypothesised that since the low temperature of $7{ }^{\circ} \mathrm{C}$ slowed the rate of proteolysis, the muscle strips at $7{ }^{\circ} \mathrm{C}$ would eventually also have shown this decrease in tension, but some hours later than the muscle strips at $37^{\circ} \mathrm{C}$.

The analysis of variance (ANOVA) of the dependable variables minimum $\mathrm{pH}$ and the time (h) post mortem at which the minimum $\mathrm{pH}$ was reached are presented in Table 3. Temperature had an effect on the rate of $\mathrm{pH}$ decline; the rate of decline was faster in muscle strips at $37{ }^{\circ} \mathrm{C}$ than in muscle strips at $7{ }^{\circ} \mathrm{C}$ (Figure. 2). The intact muscles reached a minimum $\mathrm{pH}$ value $(5.6 \pm 0.22)$ within $2 \mathrm{~h}$ after slaughter (Table 4), while muscle strips at $7{ }^{\circ} \mathrm{C}$ reached a minimum $\mathrm{pH}$ of $5.9 \pm 0.21$ at $6.4 \pm 4.51 \mathrm{~h}$ (between 300 and $600 \mathrm{~min})$ post mortem $(\mathrm{P}<0.05)$. From these results it was hypothesised that post mortem glycolysis and anaerobic production of ATP were faster in muscles at higher muscle temperatures during the rigor process, which in turn could explain the higher percentage of maximum shortening obtained at $37{ }^{\circ} \mathrm{C}(33.4 \pm 3.57 \%)$ compared to $7{ }^{\circ} \mathrm{C}(10.7 \pm 2.63 \%)$, as described earlier.

Table 3 Analysis of variance (ANOVA) of the dependable variables: minimum $\mathrm{pH}$ and the time (h) post mortem at which the minimum $\mathrm{pH}$ was reached with ostrich and deboning [intact $m$. gastrocnemius, pars interna refrigerated for $24 \mathrm{~h}$ at $4{ }^{\circ} \mathrm{C}$, excised (20 min to $1 \mathrm{~h}$ post mortem) $\mathrm{m}$. gastrocnemius, pars interna from which muscle strips were kept at respectively $7{ }^{\circ} \mathrm{C}$ and $37{ }^{\circ} \mathrm{C}$ in two separate rigometers] as main effects, as well as the Shapiro-Wilk test for non-normality

\begin{tabular}{lccccc}
\hline \multirow{2}{*}{ Source } & \multirow{2}{*}{ df } & \multicolumn{2}{c}{ Minimum $\mathrm{pH}$} & \multicolumn{2}{c}{ Time (h) of minimum $\mathrm{pH}$} \\
\cline { 3 - 6 } & & MS & $\mathrm{P}$ & $\mathrm{MS}$ & $\mathrm{P}$ \\
\hline Ostrich carcass & 5 & 0.047 & 0.2812 & 17.530 & 0.1547 \\
Deboning & 2 & 0.504 & 0.2512 & 33.160 & 0.0569 \\
Error & 9 & 0.031 & & 8.275 & \multirow{2}{*}{0.0820} \\
Shapiro-Wilk & & & 0.2353 & & \\
\hline
\end{tabular}

df - Degree of freedom

MS - Mean sum of squares

P - Probability value of F-ratio test

Table 4 Mean ( \pm standard deviation) minimum $\mathrm{pH}$ and time (h) post mortem at which the minimum $\mathrm{pH}$ values were reached, respectively, within cold-deboned (excised at $24 \mathrm{~h}$ post mortem) muscles, muscle strips from hot-deboned $\left(20 \mathrm{~min}\right.$ to $1 \mathrm{~h}$ post mortem) muscles at $7{ }^{\circ} \mathrm{C}$, and muscle strips from hot-deboned (20 min to $1 \mathrm{~h}$ post mortem) muscles at $37^{\circ} \mathrm{C}$

\begin{tabular}{lccc}
\hline \multicolumn{1}{c}{ Treatment } & Minimum $\mathrm{pH}$ & $\begin{array}{c}\text { Time }(\mathrm{h}) \text { to reach } \\
\text { minimum } \mathrm{pH}\end{array}$ & $\begin{array}{c}\text { Temperature }\left({ }^{\circ} \mathrm{C}\right) \text { at } \\
\text { minimum } \mathrm{pH}\end{array}$ \\
\hline Intact muscle & $5.85 \pm 0.22$ & $2.00 \pm 0.00$ & $32.08 \pm 4.29$ \\
Muscle strips at $7{ }^{\circ} \mathrm{C}$ & $5.94 \pm 0.21$ & $6.42 \pm 4.51$ & $7.00 \pm 0.50$ \\
Muscle strips at $37^{\circ} \mathrm{C}$ & $5.76 \pm 0.13$ & $4.83 \pm 3.82$ & $37.00 \pm 0.06$ \\
\hline
\end{tabular}

Figure 2 illustrates the changes in $\mathrm{pH}$ and the decline in muscle temperature for the intact muscle and muscle strips (at $7{ }^{\circ} \mathrm{C}$ and at $37^{\circ} \mathrm{C}$ ) from a single ostrich carcass (representative of the profiles of the other ostriches). As illustrated by the $\mathrm{pH}$ and temperature data, there was an initial decrease in $\mathrm{pH}$ of the muscle 
strip at $37{ }^{\circ} \mathrm{C}$, followed by an increase in $\mathrm{pH}$ after a minimum value had been reached. These $\mathrm{pH}$ changes were similar to changes in the intact muscle at $<4{ }^{\circ} \mathrm{C}$. In general, the $\mathrm{pH}$ for intact muscle of $\mathrm{m}$. gastrocnemius, pars interna decreased from $1 \mathrm{~h}$ post mortem to a mean minimum value of $5.85 \pm 0.22$ at $2 \mathrm{~h}$ post mortem, indicating a rapid decrease in $\mathrm{pH}$ during the first $2-3 \mathrm{~h}$ post mortem. After reaching a minimum value, the $\mathrm{pH}$ then increased to a mean value of $6.14 \pm 0.19$ at $24 \mathrm{~h}$ post mortem. Pearson \& Young (1989) have reported that for chicken, post mortem muscle glycogen levels decline to extremely low levels at approximately $2-4.5 \mathrm{~h}$ post mortem. This indicated that the muscles were in full rigor and had reached $\mathrm{pH}$ values near those found at $24 \mathrm{~h}$ post mortem in beef muscles.

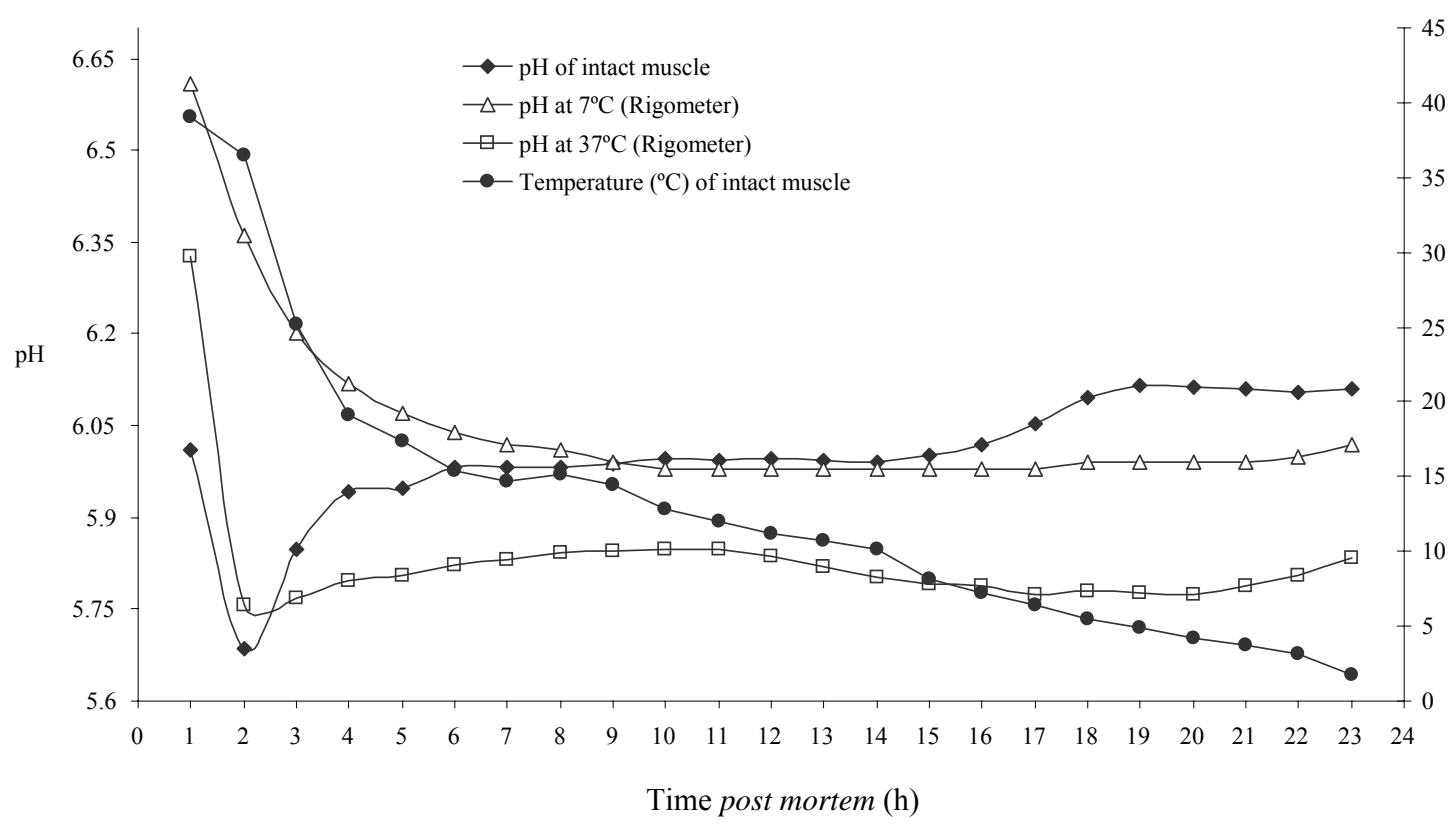

Figure 2 Hourly post mortem temperature $\left({ }^{\circ} \mathrm{C}\right)$ and $\mathrm{pH}$ values indicating the decline in temperature $(\bullet)$ and $\mathrm{pH}$ change ( $\bullet$ during the first $23 \mathrm{~h}$ post mortem for intact $m$. gastrocnemius, pars interna refrigerated at $<4{ }^{\circ} \mathrm{C}$, as well as for muscle strips from the $m$. gastrocnemius, pars interna, from the same ostrich carcass, maintained at $7{ }^{\circ} \mathrm{C}(\triangle)$ and $37^{\circ} \mathrm{C}(\square)$ in the rigometers.

The intact muscles had a mean muscle temperature of $32.1 \pm 4.29{ }^{\circ} \mathrm{C}$ at the time when the minimum $\mathrm{pH}$ was reached. It was also observed that the minimum $\mathrm{pH}$ values in both the intact muscles and the muscle strips at $37{ }^{\circ} \mathrm{C}$ were reached at approximately the same time $(\mathrm{P}>0.05)$ post mortem (Table 4$)$. The mean temperature of the muscles left intact at $1 \mathrm{~h}$ post mortem was $42.1 \pm 7.58{ }^{\circ} \mathrm{C}$, and, since muscle strips were cut from the right muscles from the same ostrich carcasses and placed in the rigometers at $1 \mathrm{~h}$ post mortem, it was assumed that the mean initial temperature $(1 \mathrm{~h}$ post mortem $)$ of the muscle strips was $>35{ }^{\circ} \mathrm{C}$. Thus, muscle strips at $37^{\circ} \mathrm{C}$ had a similar fast rate of $\mathrm{pH}$ decline during the first $2 \mathrm{~h}$ post mortem to the intact muscles. Although the muscle strips at $7{ }^{\circ} \mathrm{C}$ also had a mean initial temperature of $>35{ }^{\circ} \mathrm{C}$, their surface area to volume ratio would have resulted in the muscle strips exhibiting a rapid decline in temperature at $7{ }^{\circ} \mathrm{C}$, causing the rate of $\mathrm{pH}$ decrease to be slowed. Therefore, muscle strips at $7{ }^{\circ} \mathrm{C}$ reached a minimum $\mathrm{pH}$ at $6.4 \pm 4.51 \mathrm{~h}$ post mortem. This clearly indicates that the change in post mortem $\mathrm{pH}$ is highly temperature dependent.

The high initial ( 1 h post mortem) mean muscle temperature of $42.1 \pm 7.58{ }^{\circ} \mathrm{C}$ can be explained by outliers, as there were two individual ostrich carcasses in this study with muscle temperatures of $54.7{ }^{\circ} \mathrm{C}$ and $43.9^{\circ} \mathrm{C}$, respectively. When these outliers were removed from the data, the mean muscle temperature at $1 \mathrm{~h}$ post mortem was $37.8 \pm 0.98{ }^{\circ} \mathrm{C}$. Blight \& Hartley (1965) reported the live body temperature of ostriches to be $38.7^{\circ} \mathrm{C}$. It is hypothesised that the high muscle temperature of these two individual ostrich carcasses at $1 \mathrm{~h}$ post mortem resulted from the kicking action of the legs while the legs were fixed in the leg clamp during 
the stunning procedure (Wotton \& Sparray, 2002). The high ambient temperatures in the plucking and skinning halls would also result in the muscle temperature remaining high.

\section{Conclusions}

From the results of this study it is concluded that the rate of rigor development, the course of rigor mortis, as well as the rate of change in $\mathrm{pH}$ in ostrich $\mathrm{m}$. gastrocnemius, pars interna, are temperature dependent. These results are in accordance with the results of Hertzman et al. (1993). The degree of maximum tension and shortening was also temperature dependent. Maximum tension was higher at $7{ }^{\circ} \mathrm{C}$ than at $37^{\circ} \mathrm{C}$, while, in contrast, maximum shortening was significantly higher at $37^{\circ} \mathrm{C}$ than at $7{ }^{\circ} \mathrm{C}$. Muscle strips at $37^{\circ} \mathrm{C}$ reached a maximum tension value (completion of rigor) within $4.1 \pm 3.89 \mathrm{~h}$ post mortem, while the minimum $\mathrm{pH}$ was also reached within $4.8 \pm 3.82 \mathrm{~h}$ post mortem in muscle strips at $37{ }^{\circ} \mathrm{C}$, indicating that full rigor mortis in ostrich muscles occurred at the point of minimum $\mathrm{pH}$. The intact muscles reached a minimum $\mathrm{pH}$ at approximately $2 \mathrm{~h}$ post mortem, while muscle temperature was still relatively high $\left(32.1 \pm 4.29{ }^{\circ} \mathrm{C}\right)$. It is therefore suggested that ostrich muscles not be hot-deboned within the first $2 \mathrm{~h}$ post mortem.

\section{Acknowledgements}

This project was supported by B. Otto (General Manager) and personnel of Swartland Ostrich Abattoir, Malmesbury, South Africa, who donated the ostrich carcasses and who made it possible to conduct research at the abattoir premises. This study was also made possible by a two-year prestige scholarship from the National Research Foundation. The Norwegian Food Research Institute (MATFORSK, Ås, N-1430 Norway) is thanked for the use of their RigoTech equipment.

\section{References}

Bendall, J.R., 1973. In: The structure and function of muscle. ( $2^{\text {nd }}$ ed.) Ed. Bourne, G.H., New York, Academic Press. p. 241. (Cited by Hertzman et al., 1993).

Blight, J. \& Hartley, T.C., 1965. The deep body temperature of an unrestrained ostrich Struthio camelus recorded continuously by a radiotelemetric technique. Ibis 107, 104-105. (Cited by Swart, 1988. pp. 2.1-3.17).

Cornforth, D.P., Pearson, A.M. \& Merkel, R.A., 1980. Relationship of mitochondria and sarcoplasmic reticulum to cold-shortening. Meat Sci. 4, 103-121.

Devine, C.E., Wahlgren, N.M. \& Tornberg, E., 1999. Effect of rigor temperature on muscle shortening and tenderisation of restrained and unrestrained beef M. longissimus thoracicus et lumborum. Meat Sci. 51, 61-72.

Glass, G.V., Peckham, P.D. \& Sanders, J.P., 1972. Consequences of failure to meet assumptions underlying the fixed effects analysis of variances and covariance. Review Educ. Res. 42, 237-288.

Hertzman, C., Olsson, U. \& Tornberg, E., 1993. The influence of high temperature, type of muscle and electrical stimulation of the course of rigor, ageing and tenderness of beef muscles. Meat Sci. 35, 119-141.

Honikel, K.O., Roncalés, P. \& Hamm, R., 1983. The influence of temperature on shortening and rigor onset in beef muscle. Meat Sci. 8, 221-241.

Hwang, I.H., Devine, C.E. \& Hopkins, D.L., 2003. The biochemical and physical effects of electrical stimulation on beef and sheep meat tenderness. Meat Sci. 65, 677-691.

Kanda, T., Pearson, A.M. \& Merkel, R.A., 1977. Influence of $\mathrm{pH}$ and temperature upon calcium accumulation and release by bovine sarcoplasmic reticulum. Food Chem. 2, 253-266.

Lawrie, R.A., 1998. Meat Science. $6^{\text {th }}$ Ed. Pergamon Press, New York.

Locker, R.H. \& Daines, G.J., 1975. Rigor-mortis in beef Sterneomandibularis muscles at $37{ }^{\circ}$ C. J. Sci. Food Agri. 26, 1721-1733.

Marsh, B.B. \& Leet, N.G., 1966. Studies in meat tenderness. III. The effects of cold-shortening on tenderness. J. Food Sci. 31, 450-459.

Møller, A.J. \& Vestergaard, T., 1987. Effect of delay time before chilling on toughness in pork with high or low initial pH. Meat Sci. 19, 27-37. 
Nuss, J.I. \& Wolfe, F.H., 1980-81. Effect of post mortem storage temperatures on isometric tension, pH, ATP, glycogen and glucose-6-phosphate for selected bovine muscles. Meat Sci. 5, 201-213.

Pearson, A.M. \& Young, R.B., 1989. Post mortem changes during conversion of muscle to meat. In: Food Science and Technology, Muscle and Meat Biochemistry. Eds. Schweigert, B.S. \& S.L. Taylor, S.L., New York, Academic Press, Inc. pp. 391-425.

Powell, V.H., 1978. Proc. 24 ${ }^{\text {th }}$ Europ. Meeting Meat Res. Workers. Kulmbach. Vol. I. Paper D1. (Cited by Honikel et al., 1983).

Reologica Instruments, AB., 1999. User's manual for RigoTech Meat Analyzer, Version 3.0. Sweden.

SAS, 1999. SAS/STAT User's Guide, Version 8, $1^{\text {st }}$ printing, Volume 2. SAS Institute Inc, SAS Campus Drive, Cary, North Carolina 27513.

Shapiro, S.S. \& Wilk, M.B., 1965. An analysis of variance test for normality (complete samples). Biometrika 52, 591-611.

Smulders, F.J.M., Marsh, B.B., Swartz, D.R., Russell, R.L. \& Hoenecke, M.E., 1990. Beef tenderness and sarcomere length. Meat Sci. 28, 349-363.

Swart, D., 1988. Studies on the hatching, growth and energy metabolism of ostrich chicks. Ph.D., Agricultural Science, dissertation, University of Stellenbosch, South Africa.

Tornberg, E., 1996. Biophysical aspects of meat tenderness, Meat Sci. 43, S175-S191.

Tornberg, E., Wahlgren M., Brùndum, J. \& Engelsen, S.B., 2000. Pre-rigor conditions in beef under varying temperature- and $\mathrm{pH}$-falls studied with rigometer, NMR and NIR. Fd Chem. 69, 407-418.

Whiting, R.C., 1980. Calcium uptake by bovine muscle mitochondria and sarcoplasmic reticulum. J. Food Sci. 45, 288-292.

Wotton, S. \& Sparrey, J., 2002. Stunning and slaughter of ostriches. Meat Sci. 60, 389-394. 